\title{
Field-Based Tests for the Assessment of Physical Fitness in Children and Adolescents Practicing Sport: A Systematic Review within the ESA Program
}

\author{
Garden Tabacchi ${ }^{1,2, *(0)}$, Guillermo F. Lopez Sanchez ${ }^{3}(0)$, Fatma Nese Sahin ${ }^{4}$, Meltem Kizilyalli ${ }^{4}$, \\ Rosario Genchi ${ }^{2}$, Michele Basile ${ }^{2}$, Musa Kirkar ${ }^{2}$, Carlos Silva $\left.{ }^{5}{ }^{(}\right)$, Nuno Loureiro ${ }^{5}{ }^{\circ}$, \\ Eduardo Teixeira ${ }^{5}\left(\mathbb{D}\right.$, Yolanda Demetriou ${ }^{6}(\mathbb{D})$, David Joseph Sturm ${ }^{6}\left(\mathbb{D}\right.$, Simona Pajaujene ${ }^{7(\mathbb{D}}$, \\ Ilona J. Zuoziene ${ }^{7}$ (D), Manuel Gómez-López ${ }^{3}{ }^{(D)}$, Ante Rada ${ }^{8}$, Jelena Pausic ${ }^{8}$ (D), \\ Nemanja Lakicevic ${ }^{1}$, Luca Petrigna ${ }^{1}$, Kaltrina Feka ${ }^{1}$ (D), Ana Ribeiro ${ }^{9}$, Marianna Alesi ${ }^{1}$ and \\ Antonino Bianco 1,2 (D)
}

1 Department of Psychology, Educational Science and Human Movement, University of Palermo, Viale delle Scienze, Ed. 15, 90128 Palermo, Italy; lakinem89@gmail.com (N.L.); lucapetrigna@gmail.com (L.P.); kaltrina.feka92@gmail.com (K.F.); marianna.alesi@unipa.it (M.A.); antonino.bianco@unipa.it (A.B.)

2 Palermo University Sport Center (CUS Palermo), Via Altofonte, 80, 90129 Palermo, Italy; rosgenchi@gmail.com (R.G.); miter702@libero.it (M.B.); kirkar@ceipes.org (M.K.)

3 Department of Physical Activity and Sport, Faculty of Sports Sciences, University of Murcia, Calle Argentina, 19, 30720 Murcia, Spain; gfls@um.es (G.F.L.S.); mgomezlop@um.es (M.G.-L.)

4 Department of Sport and Health, Faculty of Sport Sciences, Ankara University, Golbasi Yerleskesi Spor Bilimleri Fakultesi, 06830 Ankara, Turkey; nesehome@hotmail.com (F.N.S.); mekizilyalli@gmail.com (M.K.)

5 Escola Superior de Desporto de Rio Maior (CIEQV - IPSantarem), Av. Dr. Mario Soares, 20413 RIO Maior, Portugal; csilva@esdrm.ipsantarem.pt (C.S.); nunoloureiro@esdrm.ipsantarem.pt (N.L.); eduardoteixeira@esdrm.ipsantarem.pt (E.T.)

6 Department of Sport and Health Sciences, Technical University of Munich, Uptown Munich Campus D, Georg-Brauchle-Ring 60/62, 80992 Munich, Germany; yolanda.demetriou@tum.de (Y.D.); david.sturm@tum.de (D.J.S.)

7 Department of Coaching Science, Lithuanian Sports University, Sporto 6, LT-44221 Kaunas, Lithuania; simona.pajaujiene@1su.lt (S.P.); ilona.zuoziene@lsu.lt (I.J.Z.)

8 Faculty of Kinesiology, University of Split, Teslina 6, 21000 Split, Croatia; arada@kifst.hr (A.R.); jelenap@kifst.hr (J.P.)

9 Escola Profissional de Aveiro, Rua Dr. Francisco Ferreira Neves. Apartado 567, Barrocas, 3800-510 Aveiro, Portugal; ana.ribeiro@epa.edu.pt

* Correspondence: tabacchi.garden@libero.it; Tel.: +39-091-23896910; Fax: +39-091-23860894

Received: 8 November 2019; Accepted: 11 December 2019; Published: 15 December 2019

\begin{abstract}
High levels of physical fitness (PF) can positively affect both health and cognitive function, thus monitoring its levels in youth can help increase health and quality of life in adult populations later on. This systematic review aims to identify PF field-based tests used in young European populations practicing sport to find tools that are adequate for the considered target involving a new battery within the Enriched Sport Activities (ESA) project. The Preferred Reporting Items for Systematic Reviews and Meta-Analyses (PRISMA) statement was followed. In the 83 identified articles, the main tests used were: vertical/horizontal jumps (for muscular strength/power); push-ups, running at maximum effort, sit-ups (for muscular strength/endurance); multistage non-intermittent and intermittent tests (for aerobic endurance); sit and reach (for flexibility); sprinting and agility $T$-tests (for speed and agility, respectively); $10 \times 5 \mathrm{~m}$ shuttle run (SR) (for both speed and agility). Few studies assessed coordination, reaction time, power, and balance. Although the selected tests are widely used and validated, they do not determine all PF aspects and do not reflect sport-specific features. A final decision was made for the inclusion of the following tests: standing broad jump, seated medicine ball throw, $20 \mathrm{~m}$ SR test, $30 \mathrm{~m}$ sprint, Illinois test, and a new test, i.e., the crunning test, to assess different
\end{abstract}


skill-related components at once. The use of this combination of tests allows for the assessment of all PF components and can help planning effective training programs and cultivate sporting talent.

Keywords: physical fitness; field-based test; children; sport; assessment

\section{Introduction}

In the simplest terms, physical fitness (PF) refers to the ability of the body systems to work in synchrony to efficiently allow our bodies to be healthy and perform activities of daily living with ease [1]. Essentially, PF can be further branched into two different categories. In terms of health-related $\mathrm{PF}$ as the first category, its key components are body composition, cardiorespiratory endurance, flexibility, muscular endurance, power, and strength. These components are key determinants of health as they can reduce the risk of chronic disease and promote well-being [1]. On the other side, the second category of PF comprehends skill-related PF and it consists of components such as speed, balance, agility, and coordination and reaction time [1]. As the name suggests, skill-related PF components are crucial in sports as the fundamental basis of performance. It should be noted that although PF is in part genetically determined, it can also be greatly affected by environmental factors, primarily in the form of physical exercise [2].

Current evidence states that sedentary behavior (SB) among children is highly common on a global scale. For instance, a recent study from Canada suggested that only $7 \%$ of children and youth aged 6-19 years participate in at least one hour of moderate to vigorous intensity physical activity (PA) per day, thus meeting the current PA recommendations from Canada, USA, UK, Australia, and the World Health Organization (WHO) [3]. Similar trends are seen in Europe as well. In a study performed in 2002, researchers concluded that only about a third of children aged 11, 13 and 15 years reported enough PA to meet the current WHO guidelines [4]. The ramifications of SB are detrimental and can affect the children's health and development to a great extent. SB has a powerful potential to alter the body composition with a tendency of reduced muscle mass and excess fat mass accumulation within a body [5]. Independently of time engaging in PA, SB increases the risk of developing type 2 diabetes [6], cardiovascular disease [6], metabolic syndrome [6], weight gain [7-9], and obesity [10,11], and of cardio-metabolic, all-cause mortality and a variety of physiological and psychological matters [12].

Furthermore, lifestyle and healthy/unhealthy behaviors established during childhood and adolescence can become lifelong habits since dramatic physiological and psychological adaptations take place at these ages [2]. It is argued that children not practicing physical exercise will never fully develop their genetic potential in terms of motor skills [11]. It is also known that the present PA is the best predictor of future PA [13-15].

Being physically active improves physical health but also affects cognitive function in a great manner. In 1989, Pate claimed that the most important reason for conducting fitness testing in youth is that this process can facilitate learning in the cognitive and affective domains [16]. Short-term exercise results in temporary changes in children's physical arousal that affect thinking processes; chronic exercise training produces structural changes in the brain and enhancements in PF [17,18]. Multiple studies point out that PA is a mechanism for beneficial structural and functional alterations to the brain (e.g., increased neurotrophins, cerebral blood flow, or grey matter volume), which, in turn, enhances cognitive outcomes [18]. In addition, regular PA leads to better circulation and oxygen supply to the brain, an increase in bone and muscle density, and a higher tolerance of stress [19]. The behavioral and psychological changes induced by a single bout of exercise are visible immediately after the beginning of exercise and vanish relatively quickly after its cessation. Neurophysiological changes, which underlie the transitory behavioral and psychological changes induced by exercise [20], can be viewed as a transient modulation of the activity of the neural networks involved in the cognitive task or the mental state of interest. In contrast, chronic effects of exercise reflect structural and durable 
changes in the organism, like angiogenesis [21], synaptogenesis [22], muscle hypertrophy [23,24], or neurogenesis [25].

Thus, it is important to tailor PA programs adjusted for children and adolescents that are formulated on evidence-based practice. Moreover, in order to access the current fitness level in children and adolescents, a proper series of tests has to be applied in the interest of adequate exercise prescription and motivation. Also, a suitable fitness regime will allow the measurement of progress during and after physical activity interventions. Most importantly, the most important use of fitness testing as a part of the comprehensive health-related curriculum is to teach our youth about the health benefits associated with a regular exercise regimen [16]. Accordingly, to objectively measure the PF, investigators often use various field-based tests that are easy to administer and cheaper than laboratory tests [26], and are an alternative way of measuring fitness components in population-based studies. Tests such as the EUROFIT, the ALPHA, or the ASSO fitness battery are often included in batteries aimed at evaluating components of PF in children and adolescents [27-29]. However, thorough literature research revealed many gaps and heterogeneity in the tools and batteries used for the assessment of PF in youth [30].

Because of the wide variety of tests assessing PF, this systematic review aims to identify and analyze the field-based tests used in the literature to assess PF in European children and adolescents practicing sport, in order to find an appropriate choice for the new fitness battery to be developed within the Enriched Sport Activities (ESA) project. Based on the aforementioned discussion, the significance of developing adequate fitness testing, such as ESA is clearly delineated. In the following sections, a systematic method and the outcome of it will be concisely displayed.

\section{Materials and Methods}

This work was conducted within the ESA Program, an Evidence-based Practice Exercise Program cofounded by the Erasmus+ Programme of the European Union (Key action: Sport-579661-EPP-1-2016-2-IT-SPO-SCP) involving collaborators in Croatia, Germany, Italy, Lithuania, Portugal, Spain, and Turkey [31]. It was designed as a multidisciplinary approach involving health and skill-related physical fitness components, developmental psychology and neuroscience research, with the general aim to enhance social inclusion, provide equal opportunities and promote psycho-physical wellbeing in school-age children with typical development and special needs [31].

The systematic literature review was aimed at collecting the most frequently used field-based tests for the assessment of PF in children and adolescents practicing sport. The Preferred Reporting Items for Systematic Reviews and Meta-Analyses (PRISMA) statement [32] were followed (File S1).

\subsection{Eligibility Criteria}

The PICOS (Population, Intervention, Comparison, Outcomes, Study design) criteria described in PRISMA [32] were used to determine the eligibility criteria.

The included population was composed of healthy children and adolescents aged 6-17 and practicing any kind of sport. Applied exclusion criteria included pre-schoolers or subjects older than 17 years, as well as non-healthy populations and populations that do not participate in sporting activities.

Only original articles reporting on the use of PF field-based tests were included; papers reporting only on the perception of PF or with other purposes were excluded. The search was limited to articles with observational study design, while trials, validation studies, reviews, meta-analyses, abstracts, books, position statements, reference values, and editorials were not included.

Any component of PF represented the outcomes assessed through field-based tests: muscular strength, muscular and cardiovascular endurance, flexibility, speed, power, agility, balance, coordination, and reaction time. Articles were included only if they were available in languages that the authors are fluent in reading, i.e., English, Italian, French, or Spanish. 


\subsection{Information Sources and Search Strategy}

PubMed (NLM) and Scopus databases were used as sources for articles published from January 2007 to October 2018 and conducted in European countries.

Single terms or a combination of the following keywords were used in order to find eligible articles combined with the AND:

Keywords1: fitness, physical fitness, sport*

Keywords2: child*, adolescen*, young, youth

Keywords3: field test*, field-based test* fitness battery

Keywords4: strength, strength endurance, endurance, muscle endurance, muscular endurance, cardiovascular endurance, flexibility, speed, power, agility, balance, coordination, reaction time.

\subsection{Study Screening}

The manuscript selection has been performed in two steps: in the first moment, the retrieved records were sent to Endnote ${ }^{\circledR}$ (version X8.1); in the second step, duplicates were removed and papers were screened against the inclusion and exclusion criteria.

Three independent researchers performed the revision of the literature and all doubts were solved through further analysis and discussed during the manual screening. The researchers were not blinded to the articles, authors, or associated institutions during the screening. The first selection was performed with the titles of the selected articles; during the second stage, the abstracts were examined to identify eligible papers. In the last stage, inclusion and exclusion criteria were applied to the full texts of the articles.

\subsection{Data Collection}

Papers identified as relevant were entered into a Microsoft Excel ${ }^{\circledR}$ (Microsoft Corp., Redmond, Washington, DC, USA) spreadsheet. The database, first author, year, country, target size, gender, number of males, number of females, age (years), age mean and standard deviation (SD), sport practiced, battery adopted, health-related physical fitness variables (body composition, muscular strength, muscular endurance, cardiorespiratory fitness, flexibility), and skill-related physical fitness variables (speed, agility, reaction time, coordination, power, balance) were the information collected in the Microsoft Excel ${ }^{\circledR}$ (Microsoft Corp., Redmond, Washington, DC, USA) spreadsheet.

\subsection{Quality Assessment}

A study quality assessment was performed for all retrieved papers by using the Newcastle-Ottawa Scale for observational studies [33,34]. Scales properly created for cohort and case-control studies were used, and for cross-sectional design papers, the scale adapted for cross-sectional studies as recommended by the Cochrane Collaboration was used [35].

The checklists for the three kinds of observational studies can be retrieved on the Internet (http://www.ohri.ca/programs/clinical_epidemiology/oxford.asp, accessed on 6 December 2019).

In particular, the checklist used for cross-sectional studies, which were the major part, consists of three major study aspects, i.e., "selection", including four items (sample representativeness, sample size, non-respondents, ascertainment of the exposure, for a maximum of 5 points); "comparability", including 1 item (controlling for confounders, for a maximum of 2 points); and "outcome", including 2 items (outcome assessment and statistical test, for a maximum of 3 points) (https://journals.plos.org/ plosone/article/file?type=supplementary\&id=info:doi/10.1371/journal.pone.0147601.s001, accessed on 6 December 2019). The maximum score that can be obtained by a study is 10 , with higher scores indicating higher quality. The authors have categorized studies with "low quality" those scoring from 0 to 4 , "fair quality" from 5 to 7 , and "high quality" from 8 to 10. 


\subsection{Choice of Fitness Tests for the ESA Battery}

The selection of the test is the final result of the activity and consultation of the Technical Expert Group (TEG 1) of the ESA Consortium (http://www.esaprogram.eu/). The proposed battery represents the final outcome of an agreement process among the seven participating countries.

At the end of the systematic approach, an internal quality assessment was made. Each partner received a list of the field tests retrieved in the literature for the specific biomotor abilities. Afterward every test was scored, providing a judgment according to the validity, inter-operator reliability, implementation cost, administration capacity, the socio-cultural context, and the adherence to the European Commission priorities and policies within the Erasmus+ Program.

\subsection{Data Synthesis}

Data were elaborated through the STATA/MP 12.1 software (StataCorp. LP, College Station, TX, USA). A description of the sample has been provided through frequencies in numbers and percentages. A narrative synthesis has been performed to describe the PF tests used in children and adolescents in a sport context.

\section{Results}

A total of 1518 items were retrieved (520 from the PubMed and 998 from the Scopus databases); after duplicates removal and additional manual search that allowed it to obtain other 94 papers, the first screening of titles and abstract yielded a total of 223 papers that were considered potentially eligible (1369 were excluded as they did not meet the inclusion criteria) (Figure 1). After the screening of full texts, 140 papers were excluded according to the exclusion criteria and a total of 83 articles [36-118] were included in the final review.
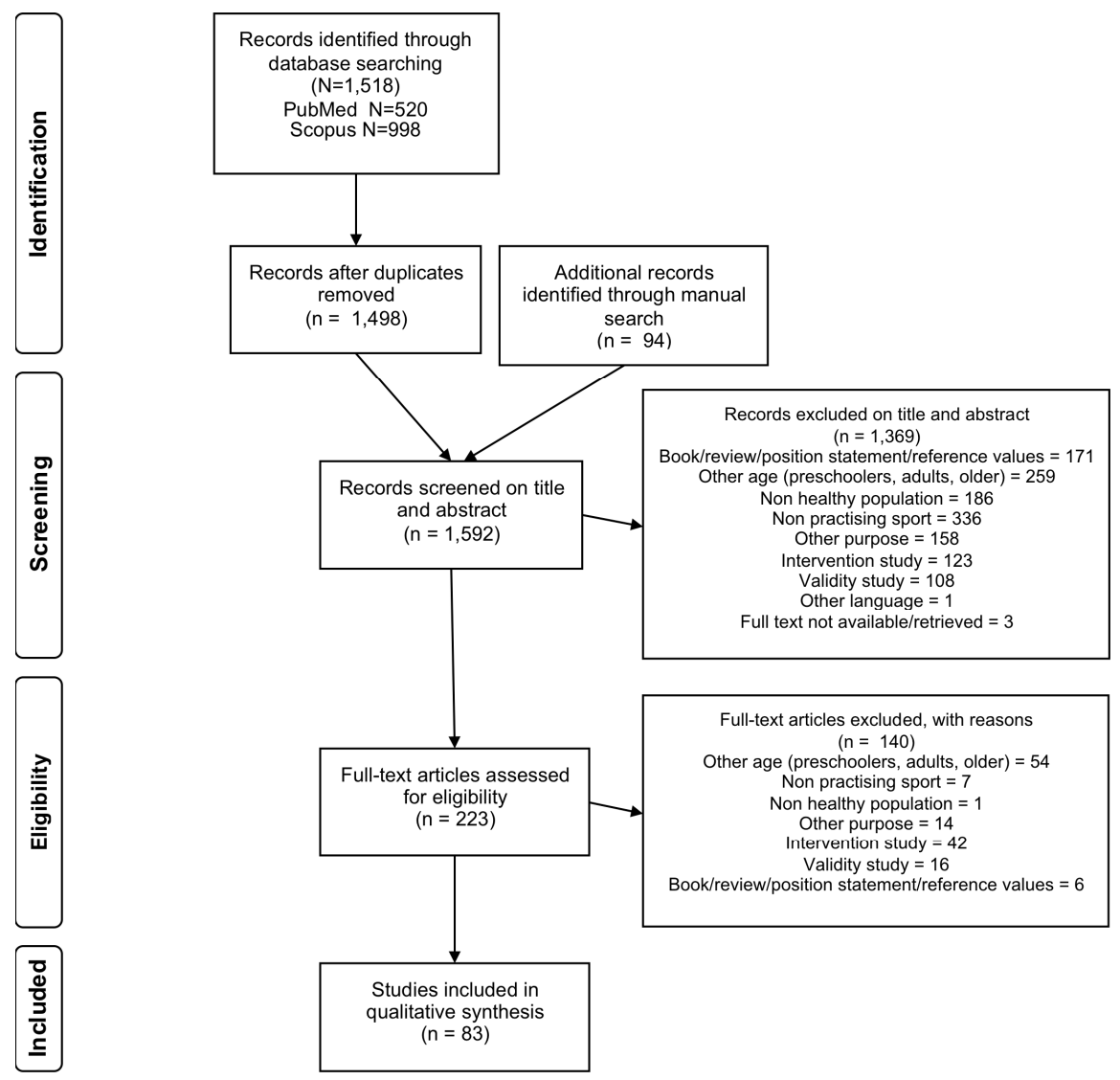

Figure 1. Flow diagram of the systematic review. 


\subsection{Overview of the Retrieved Papers}

The quality assessment revealed a total of 42 studies of fair quality, 40 of high quality, and 1 of very high quality, with a range between 5 and 9, and a mean score of 6.5 (Table S1). All studies were considered in the descriptive analysis and were discussed afterward.

As shown in Figure 2a, most studies assessing PF components in young people practicing sport were conducted in Belgium (14.5\%), Spain (14.5\%), Italy (13.3\%), United Kingdom (10.8\%), and Greece $(9.6 \%)$. Soccer and basketball were the most frequent sports mentioned in the literature $(22.9 \%$ and $15.7 \%$ of the studies, respectively), followed by tennis, rugby, gymnastics, volleyball, and others (Figure 2b).

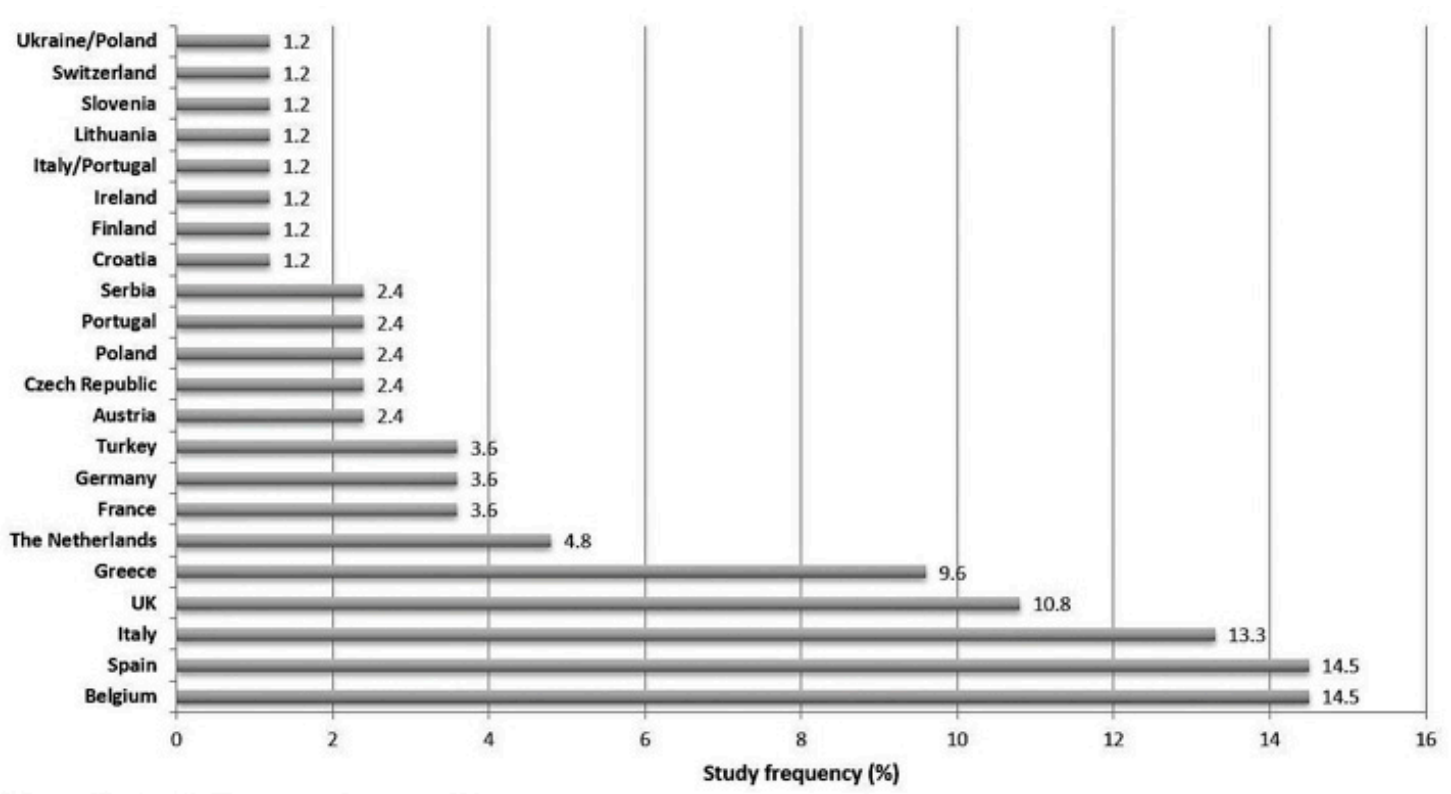

(a)

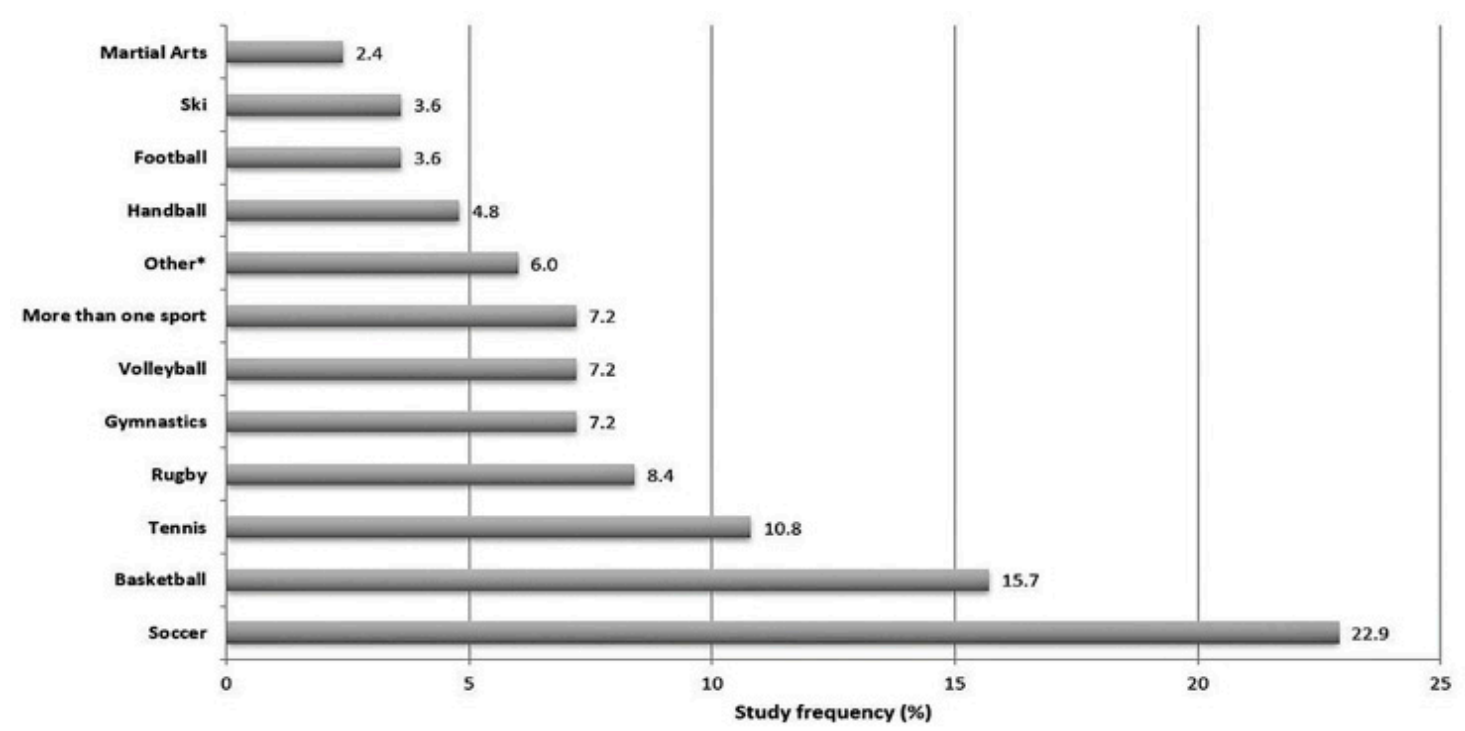

(b)

Figure 2. Study frequencies by country (a) and by type of sport (b). 
The sample ranged from 7 to 22,843 young athletes with a total of $57.8 \%$ of the studies targeted to males and only $16.9 \%$ to females; in $24.1 \%$ of the studies, both males and females were included (Figure 3a). In $10.8 \%$ of the studies, the population was composed of children with a mean age of 10 years or less (primary school), while $28.9 \%$ of the studies had participants ranging between 11 and 13 years (lower secondary school). The majority of the findings $(60.2 \%)$ involved an examination of a population aged 14 years or older (high school) (Figure 3b).

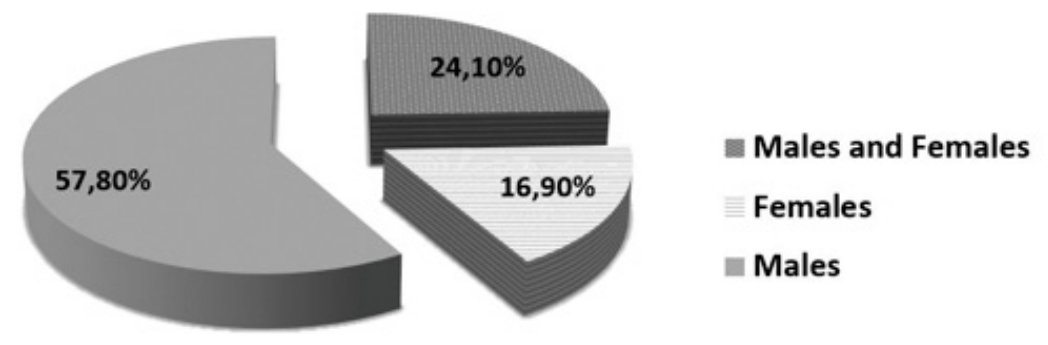

(a)

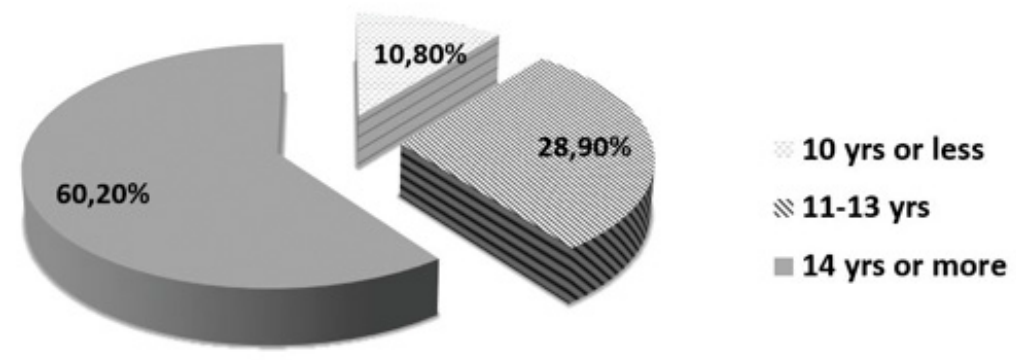

(b)

Figure 3. Study frequencies by gender (a) and by age (b).

A total of $20.5 \%$ of studies used previously established fitness batteries. Among these, $6.0 \%$ adopted the EUROFIT battery, using all tests or only a part of them; similarly, $9.6 \%$ of the studies used the Körperkoordinationstest für Kinder (KTK) in total or partially; $7.2 \%$ of the studies adopted batteries according to national sport associations/federations (such as Portuguese, Dutch, German, Swiss); 1 study used the Bruininks-Oseretsky Test Second Edition (BOT-2) battery, 1 the Hirtz's battery, and 1 the ALPHA battery.

With regard to the body composition assessment, $69.9 \%$ of the studies collected different body measures: in particular, $57.8 \%$ assessed weight and $62.7 \%$ height (sometimes including sitting height); $18.1 \%$ body fat, $4.8 \%$ body circumferences, $26.5 \%$ skinfolds, and $6.0 \%$ body lengths.

\subsection{Fitness Tests Used to Assess the Health-Related Fitness Components}

\subsubsection{Muscular Strength/Power}

Muscular strength/power was assessed through a variety of tests in 57 studies (68.7\%). Lower body strength was assessed through vertical jumps (VJs) by $70.2 \%$ of these 57 studies or by preferring the countermovement jump (CMJ) $(90.0 \%)$ (Table 1). Horizontal jumps (HJs) such as the standing broad jump (SBJ) were also frequently used by $40.4 \%$ of the 57 studies. Other jumps, such as 5 -jump test, Abalakov jump, and drop jump (DJ), were used in around $17 \%$ of those studies. Hops (two-leg 5-hop; one-leg, 5-hop) and other tests for the lower body assessment (Abdominal Strength Test-AST, 
drop jump test—DJ, 30 sec Bosco test, Romanian Deadlift, Wingate anaerobic test, and maximal voluntary repetitions of the knee) were less frequently used (Table 1).

Table 1. Frequencies of the studies assessing health-related fitness components.

\begin{tabular}{|c|c|c|c|}
\hline & & N. & $\%$ \\
\hline & MUSCULAR STRENGTH/POWER & 57 & 68.7 \\
\hline \multirow[t]{10}{*}{ Lower body } & Horizontal jumps (HJ) & 23 & 40.4 \\
\hline & Standing Broad Jump (SBJ) & 19 & 82.6 \\
\hline & HJ not specified & 4 & 17.4 \\
\hline & Vertical jumps (VJ) & 40 & 70.2 \\
\hline & VJ not specified & 4 & 10.0 \\
\hline & Countermovement jump (CMJ) * & 36 & 90.0 \\
\hline & Squat jump (SJ) & 8 & 20.0 \\
\hline & Other jumps ** & 10 & 17.5 \\
\hline & Hops $* * *$ & 2 & 3.5 \\
\hline & Other lower $* * * *$ & 5 & 8.8 \\
\hline \multirow[t]{2}{*}{ Upper body } & Dinamometry & 7 & 12.3 \\
\hline & Medicine ball ${ }^{\S}$ & 10 & 17.5 \\
\hline \multicolumn{2}{|r|}{ MUSCULAR STRENGTH/ENDURANCE } & 20 & 24.1 \\
\hline \multirow[t]{4}{*}{ Upper body } & Bent arm hanging & 2 & 10.0 \\
\hline & Bench press & 2 & 10.0 \\
\hline & Pull-ups & 1 & 5.0 \\
\hline & Push-ups & 5 & 25.0 \\
\hline \multirow[t]{3}{*}{ Lower body } & Line-drill (LD) & 1 & 5.0 \\
\hline & Rope jumping & 2 & 10.0 \\
\hline & 1000,500 and $200 \mathrm{~m}$ at maximum effort & 2 & 10.0 \\
\hline \multirow[t]{9}{*}{ Abdominal } & Sit-up/abdominals $\S \S$ & 14 & 70.0 \\
\hline & CARDIOVASCULAR ENDURANCE & 44 & 53.0 \\
\hline & Multistage tests non intermittent & 21 & 47.7 \\
\hline & Multistage tests: $20 \mathrm{~m}$ shuttle run (SR) & 4 & 19.0 \\
\hline & Multistage tests: other & 11 & 52.4 \\
\hline & Multistage tests intermittent & 15 & 34.1 \\
\hline & Yo-yo Intermittent Recovery Test (IRT) ^ & 12 & 80.0 \\
\hline & Interval Shuttle Run Test (ISRT) ^ & 2 & 13.3 \\
\hline & Other running tests ${ }^{m}$ & 6 & 13.6 \\
\hline \multirow[t]{5}{*}{ FLEXIBILITY } & & 17 & 20.5 \\
\hline & Sit and reach & 17 & 100.0 \\
\hline & Stand and reach & 2 & 11.8 \\
\hline & Shoulder test (flexibility, mobility or rotation test) & 5 & 29.4 \\
\hline & Other $^{\circ}$ & 1 & 5.9 \\
\hline
\end{tabular}

* including 1 study specifying CMJ with and without arms, and 1 with arms. ${ }^{* *} 5$-jump test, Abalakov jump, drop jump (DJ). ${ }^{* * *}$ including two-leg 5-hop; one-leg 5-hop. ${ }^{* * * *}$ Abdominal Strength Test (AST), DJ, 30 sec Bosco test, Romanian Deadlift, Wingate anaerobic test, maximal voluntary repetitions of the knee. $\$ 2 \mathrm{~kg}, 3 \mathrm{~kg}, 4 \mathrm{~kg}$, over-head, forehand and backhand, seated. $\$ \S$ only in three studies specified as 60 -sec, 30 -sec, and number of sit-ups. including 5 Yo-yo level 1; 1 Yo-yo level 2; 2 Yo-yo level 3; 3 Yo-yo not specified. " including submaximal ISRT and NAVTEN. " including 12-min run, $300 \mathrm{~m}$ and $2 \mathrm{~km}$ run, $45-15$ test $\left(=45^{\prime \prime}\right.$ running bouts performed at progressive speed, interspersed with $15^{\prime \prime}$ passive recovery), 20-m continuous progressive track run test, Cooper 12 min run test. including splits, lifts of side and leg (= side splits with right or left leg forward, right-leg lift test forward, left-leg lift test forward, right-leg lift test sideward, and left-leg lift test sideward).

Upper body strength was assessed through dynamometry (such as the handgrip test) in $12.3 \%$ of the studies and via medicine ball throw in $17.5 \%$ of the papers; the weight of the used ball ranged from 2 to $4 \mathrm{~kg}$, and in few cases, it was specified based on the way it was thrown (over-head, forehand, and backhand, seated or standing) (Table 1). 


\subsubsection{Muscular Strength/Endurance}

The muscular strength/endurance was evaluated in $24.1 \%$ of the studies, through different tests focusing on different muscle groups: bent arm hanging, bench press, pull-ups and push-ups (upper body, half of the studies); line-drill (LD) rope jumping, 1000, 500 and $200 \mathrm{~m}$ at maximum effort (lower body, five studies); sit-ups (abdominals, 14 studies) (Table 1 ).

\subsubsection{Cardiovascular Endurance}

Aerobic endurance was tested in $53.0 \%$ of the studies, through multistage non-intermittent $(47.7 \%)$ and multistage intermittent (34.1\%) tests. Among the non-intermittent tests, the most used was the $20 \mathrm{~m} \mathrm{SR}$ (almost 50\%). The Yo-yo Intermittent Recovery Test (IRT) was the most used test $(80.0 \%)$ among the intermittent multistage ones and included the Yo-yo level 1, 2, and 3.

\subsubsection{Flexibility}

Flexibility was assessed in $20.5 \%$ of the studies, and all of these studies used the sit and reach test. In addition, $29.4 \%$ used flexibility, mobility or rotation tests of the shoulder, while $11.8 \%$ used the stand and reach test.

\subsection{Fitness Tests Used to Assess the Skill-Related Fitness Components}

\subsubsection{Speed}

A total of $55.4 \%$ of the studies assessed speed, through the following tests: sprints (76.1) of 5, 10, 15, 20, 25, 30, 40, or $60 \mathrm{~m}$; Repeated Sprints Ability (RSA) tests (17.4\%) with sprint $30 \mathrm{~m}, 40 \mathrm{~m}$. or $60 \mathrm{~m}$, and split at 5, 10, 20, 30, $40 \mathrm{~m}$ (Table 2). In the $8.7 \%$ of the studies, Bangsbo sprint test, sprinting and jumping, throwing velocity, and shuttle sprint have been adopted (Table 2).

Table 2. Frequencies of the studies assessing skill-related fitness components.

\begin{tabular}{|c|c|c|}
\hline & $\mathbf{N}$ & $\%$ \\
\hline SPEED & 46 & 55.4 \\
\hline Sprint \# & 35 & 76.1 \\
\hline Repeated sprint with split time & 8 & 17.4 \\
\hline Other \#\#\# & 4 & 8.7 \\
\hline AGILITY & 21 & 25.3 \\
\hline Agility test not specified & 4 & 19.0 \\
\hline 505-agility test & 4 & 19.0 \\
\hline Illinois & 3 & 14.3 \\
\hline Agility $T$-test & 5 & 23.8 \\
\hline Other $\$$ & 11 & 52.4 \\
\hline SPEED/AGILITY & 9 & 10.8 \\
\hline $10 \times 5 \mathrm{~m}$ shuttle run $(\mathrm{SR})$ & 5 & 55.6 \\
\hline $4 \times 10 \mathrm{~m} \mathrm{SR}$ & 2 & 22.2 \\
\hline Sprint with change of direction & 2 & 22.2 \\
\hline COORDINATION & 20 & 24.1 \\
\hline Körperkoordinationstest für Kinder (KTK) & 10 & 50.0 \\
\hline Other * & 10 & 50.0 \\
\hline REACTION TIME & 3 & 3.6 \\
\hline POWER $^{\text {^ }}$ & 3 & 3.6 \\
\hline BALANCE ${ }^{m}$ & 3 & 3.6 \\
\hline
\end{tabular}

\# including 5, 10, 15, 20, 25, 30, 40, and $60 \mathrm{~m}$. \#\# sprint $30 \mathrm{~m}, 40 \mathrm{~m}$ or $60 \mathrm{~m}$, split at 5, 10, 20, 30, and 40 m. \#\#\# Bangsbo sprint test; sprinting and jumping; throwing velocity; shuttle sprint. \$ Barrow zig-zag run test modified; Cross-hopping test; hurdles agility test; 15 m agility run; agility run $4 \times 15$ m; L-Run agility test; Pro-agility test; Side test; Spider run test; time in a slalom course without and with a ball; $2 \times 15 \mathrm{~m}$; zig-zag agility drill; Illinois ball dribbling. * Obstacle run; walk backwards (WB); plate tapping; eye-hand-foot coordination; hurdle boomerang run test; low jump test; orientation SR test. ^ speed while dribbling test; simple reaction time test; react to one given signal from the five proposed. " Ball throw test; double-Leg to Single-Leg Landing; single Leg Squat. ${ }^{m}$ Two studies used the Flamingo test; one study involved standing on one leg lengthwise on a bench as part of the test. 


\subsubsection{Agility}

Agility was assessed by $25.3 \%$ of the retrieved studies. The most used test was the agility T-test ( $23.8 \%)$, followed by the 505 -agility test $(19.0 \%)$, and the Illinois test $(14.3 \%)$. In $19 \%$ of the studies, the agility test used was not specified. Other types of analysis were used in $52.4 \%$ of the studies: hexagon, such as the modified Barrow zig-zag run test, Cross-hopping test, hurdles agility test, $15 \mathrm{~m}$ agility run, agility run $4 \times 15 \mathrm{~m}$, L-Run agility test, Pro-agility test, Side test, Spider run test, time in a slalom course without and with a ball, $2 \times 15 \mathrm{~m}$, zig-zag agility drill, and Illinois ball dribbling (Table 2).

\subsubsection{Speed and Agility}

A total of $12.2 \%$ of the studies used tests evaluating both speed and agility. The most commonly used test was the sprint with changes of direction (40\%), followed by the $10 \times 5 \mathrm{~m} \mathrm{SR}(33.3 \%)$ and $4 \times 10 \mathrm{~m}$ SR $(26.7 \%)$ (Table 2).

\subsubsection{Coordination}

The studies assessing coordination (10.8\%) used the KTK (50\%), and the other half used Obstacle run, walk backwards (WB), plate tapping, eye-hand-foot coordination, hurdle boomerang run test, low jump test, and orientation SR test (Table 2).

\subsubsection{Reaction Time, Power and Balance}

A few studies assessed reaction time, power, and balance (3.6\%); for the last component, the Flamingo balance test was mainly used (Table 2).

\subsection{Sport-Specific Fitness Tests Used to Assess the Health-and Skill-Related Fitness Components}

In soccer, the most specific used tests were the Hoff test, the ability of ball control, ball control with the head, pass accuracy, shooting accuracy, dribbling and dribbling with the pass, speed spot shooting, defensive movement, and a throw-in for distance. For basketball, investigators used speed spot shooting, passing, control dribble, defensive movement, shot, lay-up, and the two-handed chest pass to examine the health- and skill-related fitness components. For tennis, the serve velocity, the tennis-specific endurance field test (SET-Test), and the tennis-specific sprint were used. In water-sports, investigators used the Hiking endurance with incremental resistance (Bucket test, sailing specific); sprint swimming, endurance swimming, and hydrodynamic tests. In gymnastics, the rope-climbing tests was used. For skiing, the Swiss-Ski Power Test was used.

\section{Discussion}

The present study provides a framework of the field-based tests adopted to assess PF in children and adolescents practicing sport across European countries. High heterogeneity was evidenced among the used tests for health- and skill-related fitness assessment. As expected, muscular strength and power were frequently assessed, especially in sports such as soccer, basketball, tennis, and rugby. Vertical and horizontal jumps (i.e., the SBJ) were commonly used to determine lower body strength. Even though the VJs were widely used in the literature, the SBJ was finally considered for the ESA fitness battery, since, it doesn't require expensive equipment like force platforms, infrared system, accelerometer or mechanical instruments, and is widely recognized as a valid test to measure lower body muscular strength and upper body muscular strength in youth $[119,120]$. Moreover, the ESA Consortium agreed on implementing the SBJ rather than the VJ, since it is less demanding for instructors and participants and shows a high level of inter-operator reliability.

For the upper body strength, most of the studies used the medicine ball throw, followed by the handgrip. The use of handgrip dynamometry for the measurement of maximum isometric strength in athletes has been reported in many papers and discussed only in two reviews [121]. Although different articles in the literature addressed its validity, reliability, and standardization [121-123], it requires rigid 
adherence to clinical, practical, and sports specific testing protocols to provide adequate monitoring of athletes [124]. In regards to the medicine ball throw, some studies reported on its validity and use for assessment of the upper extremity physical performance in all age groups, including athletic populations, and it appears to be a promising tool for the ESA program purposes [125-129].

Literature shows that seated medicine ball throw (SMBT) is a highly reliable and reasonably valid test for assessing upper body muscular power in the adults [130]. In nearly 400 medicine ball throws, with a variety of subjects, no injuries or complaints of discomfort occurred [130]. Moreover, some authors stated that participants enjoyed the test [130]. Notably, SMBT is cheap and easy to perform [130]. This represents a real advantage since many power tests use equipment that is costly and requires rigorous training of the practitioner [130]. For this reason, it has been considered by the authors as a suitable test to assess the upper body (arm) strength and explosive power for the battery to be developed within the ESA project.

With regard to cardiovascular endurance, most studies used non-intermittent tests such as the $20 \mathrm{~m}$ shuttle run test. This test is widely recognized in the literature as an effective tool to assess aerobic performance in athletes of all levels, from children to elite athletes, in all sports [131-135], and consequently in cardiorespiratory fitness [136]. The test it can highly predict both $\mathrm{VO}_{2}$ max and the velocity of $\mathrm{VO}_{2} \max \left(\mathrm{vVO}_{2} \max\right.$ ) [137-139]. Furthermore, it requires low costs, it is easy to administer and presents a very good test-retest reliability and validity while being able to test large groups of children simultaneously [140]. Therefore, it was suitable to be included in the ESA fitness battery to evaluate aerobic performance.

More than half of the studies used tests to assess "speed" as a skill-related component of fitness, such as sprint tests with and without split times. Among the sprints, because running speed and Illinois test, which is an agility test, can be used interchangeably [141], the $30 \mathrm{~m}$ sprint was included by the ESA team in the battery since it also requires acceleration, allowing us to obtain more information. Furthermore, this test was the most frequently used across all the considered tests and it is valid and reliable [142,143], beyond being highly relevant to team-sports performance [144-147].

Speed/Agility was measured through a variety of tests, and among them, the Illinois test, which involves straight-line sprints and rapid change of directions in varying sides and magnitudes, was used quite frequently. It was considered within the ESA project, as it can represent a valid measure of agility in different sports and in school-age children [68,141,148-151].

Additionally, in comparison with the T test and the Hexagon test, this test has components that replicate movement patterns of field team sports such as soccer, rugby, and handball [141]. Finally, but not less important, the Illinois test is a reliable and valid test to measure the change of directions [141]. Apart from high overall validity [141], the test could have an advantage in terms of ecological validity as it includes generic cues that closely replicate the majority of movement patterns performed in specific sports such as soccer [148].

Most of the studies assessing the coordination of young athletes used the KTK, a valid test aimed at determining the gross motor coordination in school-aged children [152-154]. The ESA team has considered a new test, the "Crunning Test", to assess coordination and various other skill-related components of physical fitness. This test is a combination of crawling and running, and envisages a quadruped position to exercise the shoulders and arms, providing a complete body workout. The "crawling" exists in 21 different variations and to the authors' knowledge, it has been very poorly used in the past $[155,156]$. It is a full-body cardio exercise that improves balance and mobility, boosts coordination, stabilizes and strengthens the core, and engages the shoulders, abdominals, gluteus, hips, quads, and calves $[155,156]$. Based on the variation used, abdominal muscles, back muscles and other core muscles are contracted to maintain that position and propel. Moreover, during the crawling the vestibular system, a sensory system associated with balance and spatial orientation, is involved, with a kind of reset stimulus that takes back to revisiting the mobility patterns one has learned as a baby $[155,156]$. 
Therefore, beyond motor skills, the central nervous system is also involved in this type of exercise [157]. Different websites report the theory of "central nervous system resetting" during crawling gaits that explains how the human brain in adults tries to synchronize coordination, movement, and reflexive stability, helping the body regain strength, mobility, and stability one had in their youth. Unfortunately, as far as we know, scientific evidence does not support this construct.

One limitation of this literature review is that it is restricted to European countries. This choice was driven by the fact that the ESA Program is a European project, and the authors tried to focus on gaps in the assessment of fitness components only on children from European countries. The base concept was to focus on more limited aspects in order to restrict the search and create more targeted and exclusive tools characteristic of similar contexts and cultures. Thus, the European literature was explored with regard to the PF tests used in youth, in order to find an appropriate battery for the European ESA project. Moreover, a lack of studies conducted in some European countries was evidenced, with this contributing to possible publication bias. It is not clear whether those studies are not published or were published in other local languages and thus could not be retrieved. Nonetheless, all studies retrieved were judged by the authors to have a fair or high quality of sample size, methodology and statistics used, thus reducing the risk of bias.

Another source of bias could have been that some studies were unclear about the precise method used. In line with this issue, Petrigna et al., recently highlighted how important it is to report and consequently adopt proper Standard Operating Procedures (SOPs) related to every single test adopted [158].

In summary, this study reports on the field-based fitness tests used in the context of different sports in young populations. Previous studies examined the use of such tests in the school context, but the present findings add information specifically in the sports context with the intent to fill the gaps in the literature regarding fitness components' assessment.

Different fitness test batteries have been developed for school-age children. The EUROFIT Physical Fitness Test Battery was developed by the Council of Europe for the use within the school environment since 1988 and included tests for the health-related fitness components assessment [28]. Nonetheless, those tests do not assess all aspects of PF and do not reflect the specific features of different kinds of sports. The ALPHA battery examined as well the health-related PF in young populations [27]. Subsequently, the ASSO-Fitness Test Battery was addressed to school adolescents with the aim of collecting information on their fitness level, as well with particular attention to the health-related fitness components $[29,30,159]$. These traditional methods of assessing the PF components in young populations only partially reflect the needs for athletic skills assessment in the pediatric age and needs of the ESA Consortium. Further development of the fitness assessment battery is now envisaged within the ESA project, where fitness is analyzed in the sports context for young people, and cognitive skills are also considered together with motor components and technical skills. In fact, cognitive processing skills such as decision-making and perception are also important in athletic performances, and priority should be given to the assessment of such aspects in the public health context. Moreover, feasibility, sustainability and effectiveness in measuring all the health-related and skill-related fitness components should be basic aspects of a fitness test battery aimed at monitoring children and adolescents practicing sport. This search was useful to authors for the choice of the most suitable tests in the context of the youth sport environment within the EU priorities and the EACEA Erasmus+ Program. Starting from the results of the literature, the test selection was made according to the scoring of the Consortium of every single test adopting the following key factors: (a) implementation cost; (b) validity and inter-operator reliability; (c) socio-cultural context; (d) European Commission Policies and Priorities. Some of the most frequently used tests were confirmed, such as the standing broad jump, the seated ball throw, the $20 \mathrm{~m}$ SR test, the $30 \mathrm{~m}$ sprint, and the Illinois agility test, while a new one was chosen (i.e., the Crunning Test), as they all received the highest scores, and they were in line with the need for encompassing the assessment of different skills together, and of assessing and developing at the same time cognitive skills and PA (Table 3). 
Table 3. Summary of the new ESA Fitness Test Battery (ESA-FTB).

\begin{tabular}{|c|c|c|}
\hline FITNESS TEST & $\begin{array}{c}\text { Main Fitness Component/s } \\
\text { Measured }\end{array}$ & Detailed Item/s Measured \\
\hline seated ball throw & Muscular strength/power & Explosive strength of upper limbs, Power \\
\hline standing long jump & Muscular strength/power & Explosive strength of lower limbs, Power \\
\hline $20 \mathrm{~m} \mathrm{sr}$ & Cardiovascular endurance & $\begin{array}{c}\text { Maximum volume of } \\
\text { oxygen consumption }\left(\mathrm{VO}_{2}\right)\end{array}$ \\
\hline $30 \mathrm{~m}$ sprint & Speed & $\begin{array}{l}\text { Reaction speed, joint flexibility, Speed, } \\
\text { Reaction time }\end{array}$ \\
\hline illinois test & Agility, speed, coordination & $\begin{array}{l}\text { Speed endurance and coordination of lower } \\
\text { limbs, reaction time }\end{array}$ \\
\hline crunning test (ESA TEST) & $\begin{array}{l}\text { Agility, speed, coordination, } \\
\text { balance, power, reaction time }\end{array}$ & Skill related components of physical fitness \\
\hline
\end{tabular}

The Illinois agility test was considered suitable for ESA, since it requires at the same time memory and planning. The $20 \mathrm{~m}$ SR test was included in the test battery because it is standardized, requires little equipment and it is relatively easy to conduct and administer. Finally, a new fitness test that has not been used yet called the Crunning test (also called ESA test) was considered in order to assess all different skills at the same time; it could have a certain efficacy in the assessment of coordination, agility, speed, and power simultaneously, while also requiring the involvement of the central nervous system. Considering the nature of the project, this represents a priority for the ESA Consortium. All these tests included in the ESA battery were field-based tests that are easy to administer, allow the assessment of all components of PF in short periods, and also include cognitive aspects. Motor and cognitive performances are combined in the ESA tool to accurately assess young athlete abilities and skill performance in sports clubs or fitness centers with the aim of planning effective training programs and raising new sport talents. Readers can find more info by visiting the projects' official website: http://www.esaprogram.eu/.

Supplementary Materials: The following are available online at http://www.mdpi.com/2071-1050/11/24/7187/s1. File S1: PRISMA checklist; Table S1: Quality scores of the individual studies.

Author Contributions: Conceptualization, G.T. and A.B.; Methodology, G.T., G.F.L.S., M.K. (Meltem Kizilyalli); Formal Analysis, G.T.; Data Curation, G.T., G.F.L.S., M.K. (Meltem Kizilyalli); Writing-Original Draft Preparation, G.T.; Writing—Review \& Editing, A.B.; Visualization, M.A., F.N.S., R.G., M.B., M.K. (Musa Kirkar), C.S., N.L. (Nemanja Lakicevic), E.T., Y.D., D.J.S., S.P., I.J.Z., M.G.-L., A.R. (Ante Rada), J.P., N.L. (Nuno Loureiro), L.P., K.F., A.R. (Ana Ribeiro); Supervision, A.B.; Project Administration, A.B., M.A.; Funding Acquisition, A.B., M.A.

Funding: The work was conducted within the ESA (Enriched Sport Activities) Program-Agreement number 2016-3723/001-001, funded by the Erasmus Plus Sport Programme (2017-2019) of the European Commission. Erasmus+ Sport Programme. EAC/A04/2015 - Round 2 E+ SPORT PROJECT: 579661-EPP-1-2016-2-IT-SPO-SCP. Enriched Sport Activities Program.

Acknowledgments: We are grateful to all people that make possible the ESA Program's successful implementation. First of all, we are thankful to the (Istituto San Francesco D'Assisi); the key school in which the ESA Program was born. We will never forget how helpful and kind were all Sisters involved; greatly managed by "Sister Angela Maria". We are also in debt with the all MSc Students in Sport and Exercise Sciences of Palermo University: Federico Giglio, Giovanna Panzica, Martina Barca, Nadia Randazzo, Paola Vaccaro, Vanessa Vaccaro, Gianluca Vivona. ESA's fitness test battery success is also coming from their precious daily help.

Conflicts of Interest: The authors declare no conflict of interest.

\section{References}

1. Corbin, C.B. Fitness for Life; Human Kinetics: Champaign, IL, USA, 2014.

2. Ortega, F.B.; Ruiz, J.R.; Castillo, M.J.; Sjostrom, M. Physical fitness in childhood and adolescence: A powerful marker of health. Int. J. Obes. 2008, 32, 1-11. [CrossRef] [PubMed] 
3. Tremblay, M.S.; LeBlanc, A.G.; Kho, M.E.; Saunders, T.J.; Larouche, R.; Colley, R.C.; Goldfield, G.; Gorber, S.C. Systematic review of sedentary behaviour and health indicators in school-aged children and youth. Int. J. Behav. Nutr. Phys. Act. 2011, 8, 98. [CrossRef] [PubMed]

4. Serdula, M.K.; Ivery, D.; Coates, R.J.; Freedman, D.S.; Williamson, D.F. Do obese children become obese adults? A review of the literature. Prev. Med. 1993, 22, 167-177. [CrossRef] [PubMed]

5. Grontved, A.; Hu, F.B. Television viewing and risk of type 2 diabetes, cardiovascular disease, and all-cause mortality: A meta-analysis. JAMA 2011, 305, 2448-2455. [CrossRef] [PubMed]

6. Bankoski, A.; Harris, T.B.; McClain, J.J.; Brychta, R.J.; Caserotti, P.; Chen, K.Y.; Berrigan, D.; Troiano, R.P.; Koster, A. Sedentary activity associated with metabolic syndrome independent of physical activity. Diabetes Care 2011, 34, 497-503. [CrossRef] [PubMed]

7. Mekary, R.A.; Feskanich, D.; Malspeis, S.; Hu, F.B.; Willett, W.C.; Field, A.E. Physical activity patterns and prevention of weight gain in premenopausal women. Int. J. Obes. 2009, 33, 1039-1047. [CrossRef]

8. Wijndaele, K.; Lynch, B.M.; Owen, N.; Dunstan, D.W.; Sharp, S.; Aitken, J.F. Television viewing time and weight gain in colorectal cancer survivors: A prospective population-based study. Cancer Causes Control 2009, 20, 1355-1362. [CrossRef]

9. Mozaffarian, D.; Hao, T.; Rimm, E.B.; Willett, W.C.; Hu, F.B. Changes in diet and lifestyle and long-term weight gain in women and men. N. Engl. J. Med. 2011, 364, 2392-2404. [CrossRef]

10. Hu, F.B.; Li, T.Y.; Colditz, G.A.; Willett, W.C.; Manson, J.E. Television watching and other sedentary behaviors in relation to risk of obesity and type 2 diabetes mellitus in women. JAMA 2003, 289, 1785-1791. [CrossRef]

11. Myer, G.D.; Faigenbaum, A.D.; Edwards, N.M.; Clark, J.F.; Best, T.M.; Sallis, R.E. Sixty minutes of what? A developing brain perspective for activating children with an integrative exercise approach. Br. J. Sports Med. 2015, 49, 1510-1516. [CrossRef]

12. Currie, C.; Roberts, C.; Settertobulte, W.; Morgan, A.; Smith, R.; Samdal, O.; Barnekow Rasmussen, V. Young People's Health in Context: Health Behaviour in School-aged Children (HBSC) Study: International Report from the 2001/2002 Survey; WHO Regional Office for Europe: Copenhagen, Denmark, 2004.

13. Faigenbaum, A.D.; Rebullido, T.R.; MacDonald, J.P. Pediatric Inactivity Triad: A Risky PIT. Curr. Sports Med. Rep. 2018, 17, 45-47. [CrossRef] [PubMed]

14. Tabacchi, G.; Faigenbaum, A.; Jemni, M.; Thomas, E.; Capranica, L.; Palma, A.; Breda, J.; Bianco, A. Profiles of Physical Fitness Risk Behaviours in School Adolescents from the ASSO Project: A Latent Class Analysis. Int. J. Environ. Res. Public Health 2018, 15, 1933. [CrossRef] [PubMed]

15. Hagger, M.S. Habit and physical activity: Theoretical advances, practical implications, and agenda for future research. Psychol. Sport Exerc. 2018, 42, 118-129. [CrossRef]

16. Pate, R.R. The Case for Large-Scale Physical Fitness Testing in American Youth. Pediatric Exerc. Sci. 1989, 1, 290-294. [CrossRef]

17. Tomporowski, P.D.; McCullick, B.A.; Pesce, C. Enhancing Children's Cognition with Physical Activity Games; Human Kinetics: Champaign, IL, USA, 2015.

18. Gunnell, K.E.; Poitras, V.J.; LeBlanc, A.; Schibli, K.; Barbeau, K.; Hedayati, N.; Ponitfex, M.B.; Goldfield, G.S.; Dunlap, C.; Lehan, E.; et al. Physical activity and brain structure 2015, brain function, and cognition in children and youth: A systematic review of randomized controlled trials. Ment. Health Phys. Act. 2018, 15, 800 .

19. Frischenschlager, E.; Gosch, J. Active Learning-Leichter lernen durch Bewegung. Erzieh. Unterr. 2012, $162,131-137$.

20. McMorris, T.; Tomporowski, P.D.; Audiffren, M. Exercise and Cognitive Function; Wiley: Oxford, UK; Hoboken, NJ, USA, 2009.

21. Swain, R.A.; Harris, A.B.; Wiener, E.C.; Dutka, M.V.; Morris, H.D.; Theien, B.E.; Konda, S.; Engberg, K.; Lauterbur, P.C.; Greenough, W.T. Prolonged exercise induces angiogenesis and increases cerebral blood volume in primary motor cortex of the rat. Neuroscience 2003, 117, 1037-1046. [CrossRef]

22. Chu, C.J.; Jones, T.A. Experience-dependent structural plasticity in cortex heterotopic to focal sensorimotor cortical damage. Exp. Neurol. 2000, 166, 403-414. [CrossRef]

23. Taber, C.B.; Vigotsky, A.; Nuckols, G.; Haun, C.T. Exercise-Induced Myofibrillar Hypertrophy is a Contributory Cause of Gains in Muscle Strength. Sports Med. 2019, 49, 993-997. [CrossRef]

24. American College of Sports Medcine. American College of Sports Medicine position stand. Progression models in resistance training for healthy adults. Med. Sci. Sports Exerc. 2009, 41, 687-708. [CrossRef] 
25. Van Praag, H.; Christie, B.R.; Sejnowski, T.J.; Gage, F.H. Running enhances neurogenesis, learning, and long-term potentiation in mice. Proc. Natl. Acad. Sci. USA 1999, 96, 13427-13431. [CrossRef] [PubMed]

26. Heyward, V.H. Advanced Fitness Assessment and Exercise Prescription, 3rd ed.; Human Kinetics: Champaign, IL, USA, 1991; pp. 1-50.

27. Ruiz, J.R.; Castro-Pinero, J.; Espana-Romero, V.; Artero, E.G.; Ortega, F.B.; Cuenca, M.M.; Jimenez-Pavon, D.; Chillon, P.; Girela-Rejon, M.J.; Mora, J.; et al. Field-based fitness assessment in young people: The ALPHA health-related fitness test battery for children and adolescents. Br. J. Sports Med. 2011, 45, 518-524. [CrossRef] [PubMed]

28. Adam, C.; Klissouras, V.; Ravazzolo, M.; Renson, R.; Tuxworth, W. EUROFIT: European Test of Physical Fitness; Council of Europe, Committee for the Development of Sport: Rome, Italy, 1988; pp. 10-70.

29. Tabacchi, G.; Bianco, A.; Alessi, N.; Jemni, D. Design, Implementation, and Evaluation of the Adolescents and Surveillance System for the Obesity Prevention Project. Medicine 2016, 95, e3143. [CrossRef] [PubMed]

30. Bianco, A.; Jemni, M.; Thomas, E.; Patti, A.; Paoli, A.; Roque, J.R.; Palma, A.; Mammina, C.; Tabacchi, G. A Systematic Review to Determine Reliability and Usefulness of the Field-Based Test Batteries for the Assessment of Physical Fitness in Adolescents-the Asso Project. Int. J. Occup. Med. Environ. Health 2015, 28, 445-478. [CrossRef] [PubMed]

31. Bianco, A.; Sahin, F.N.; Kizilyalli, M.; Genchi, R.; Basile, M.; Silva, C.; Loureiro, N.; Demetriou, Y.; Beckmann, J.; Pajaujiene, S.; et al. Physical Fitness and Motor Coordination Monitoring during Enriched Sport Activities in a Sample of Children Living in Europe. The Esa Program. Acta Med. Mediterr. 2018, 34, 11-12.

32. Moher, D.; Liberati, A.; Tetzlaff, J.; Altman, D.G.; The PRISMA Group. Preferred reporting items for systematic reviews and meta-analyses: The PRISMA Statement. Open Med. 2009, 151, 264-269.

33. Wells, G.; Shea, B.; O'Connell, D.; Petersen, J.; Welch, V.; Losos, M.T.P. The Newcastle-Ottawa Scale (NOS) for Assessing the Quality if Nonrandomized Studies in Meta-Analyses; Ottawa Hospital Research Institute: Ottawa, ON, Canada, 2012; Available online: http://www.ohri.ca/programs/clinical_epidemiology/oxford.asp (accessed on 6 January 2019).

34. Reeves, C.B.; Deeks, J.J.; Higgins, J.P.T.; Wells, A.G. Cochrane Handbook: Special Topics: Ch 13: Including non-randomized studies. In Cochrane Handbook for: Systematic Reviews of Interventions; Higgins, J.P.T., Thomas, J., Green, S., Eds.; Wiley-Blackwell: Hoboken, NJ, USA, 2011; pp. 389-432.

35. Lundh, A.; Gotzsche, P.C. Recommendations by Cochrane Review Groups for assessment of the risk of bias in studies. BMC Med. Res. Methodol. 2008, 8, 22. [CrossRef]

36. Baiget, E.; Iglesias, X.; Rodriguez, F.A. Aerobic Fitness and Technical Efficiency at High Intensity Discriminate between Elite and Subelite Tennis Players. Int. J. Sports Med. 2016, 37, 848-854. [CrossRef]

37. Bidaurrazaga-Letona, I.; Carvalho, H.M.; Lekue, J.A.; Badiola, A.; Figueiredo, A.J.; Gil, S.M. Applicability of an agility test in young players in the soccer field. Rev. Bras. Med. Esporte 2015, 21, 133-138. [CrossRef]

38. Callewaert, M.; Boone, J.; Celie, B.; De Clercq, D.; Bourgois, J.G. Indicators of sailing performance in youth dinghy sailing. Eur. J. Sport Sci. 2015, 15, 213-219. [CrossRef]

39. Castagna, C.; Impellizzeri, F.M.; Rampinini, E.; D'Ottavio, S.; Manzi, V. The Yo-Yo intermittent recovery test in basketball players. J. Sci. Med. Sport 2008, 11, 202-208. [CrossRef] [PubMed]

40. Castagna, C.; Manzi, V.; Impellizzeri, F.; Weston, M.; Barbero Alvarez, J.C. Relationship between endurance field tests and match performance in young soccer players. J. Strength Cond. Res. 2010, 24, 3227-3233. [CrossRef] [PubMed]

41. Coelho-E-Silva, M.J.; Vaz, V.; Simões, F.; Carvalho, H.M.; Valente-Dos-Santos, J.; Figueiredo, A.J.; Pereira, V.; Vaeyens, R.; Philippaerts, R.; Elferink-Gemser, M.T.; et al. Sport selection in under-17 male roller hockey. J. Sports Sci. 2012, 30, 1793-1802. [CrossRef] [PubMed]

42. Condello, G.; Minganti, C.; Lupo, C.; Benvenuti, C.; Pacini, D. Evaluation of change-of-direction movements in young rugby players. Int. J. Sports Physiol. Perform. 2013, 8, 52-56. [CrossRef]

43. Coughlan, G.F.; Delahunt, E.; Caulfield, B.M.; Forde, C.; Green, B.S. Normative adductor squeeze test values in elite junior rugby union players. Clin. J. Sport Med. 2014, 24, 315-319. [CrossRef]

44. Deprez, D.; Fransen, J.; Boone, J.; Lenoir, M.; Philippaerts, R.; Vaeyens, R. Characteristics of high-level youth soccer players: Variation by playing position. J. Sports Sci. 2015, 33, 243-254. [CrossRef]

45. Deprez, D.; Valente-Dos-Santos, J.; Coelho-e-Silva, M.J.; Lenoir, M.; Philippaerts, R.; Vaeyens, R. Longitudinal Development of Explosive Leg Power from Childhood to Adulthood in Soccer Players. Int. J. Sports Med. 2015, 36, 672-679. [CrossRef] 
46. Di Cagno, A.; Battaglia, C.; Giombini, A.; Piazza, M.; Fiorilli, G.; Calcagno, G.; Pigozzi, F.; Borrione, P. Time of Day-Effects on Motor Coordination and Reactive Strength in Elite Athletes and Untrained Adolescents. J. Sports Sci. Med. 2013, 12, 182-189.

47. Douda, H.T.; Toubekis, A.G.; Avloniti, A.A.; Tokmakidis, S.P. Physiological and anthropometric determinants of rhythmic gymnastics performance. Int. J. Sports Physiol. Perform. 2008, 3, 41-54. [CrossRef]

48. Fargeas-Gluck, M.A.; Leger, L.A. Comparison of two aerobic field tests in young tennis players. J. Strength Cond. Res. 2012, 26, 3036-3042. [CrossRef]

49. Francioni, F.M.; Figueiredo, A.J.; Terribili, M.; Tessitore, A. Analysis of the intraseasonal stability of field test performances in young academy soccer players. J. Sports Sci. 2016, 34, 966-972. [CrossRef] [PubMed]

50. Fransen, J.; Pion, J.; Vandendriessche, J.; Vandorpe, B.; Vaeyens, R.; Lenoir, M.; Philippaerts, R.M. Differences in physical fitness and gross motor coordination in boys aged 6-12 years specializing in one versus sampling more than one sport. J. Sports Sci. 2012, 30, 379-386. [CrossRef] [PubMed]

51. Gorski, T.; Rosser, T.; Hoppeler, H.; Vogt, M. An anthropometric and physical profile of young swiss alpine skiers between 2004 and 2011. Int. J. Sports Physiol. Perform. 2014, 9, 108-116. [CrossRef] [PubMed]

52. Goto, H.; Morris, J.G.; Nevill, M.E. Match analysis of U9 and U10 english premier league academy soccer players using a global positioning system: Relevance for talent identification and development. J. Strength Cond. Res. 2015, 29, 954-963. [CrossRef]

53. Karalejic, M.; Jakovljevic, S.; Macura, M. Anthropometric characteristics and technical skills of 12 and 14 year old basketball players. J. Sports Med. Phys. Fit. 2011, 51, 103-110.

54. Katis, A.; Kellis, E. Effects of small-sided games on physical conditioning and performance in young soccer players. J. Sports Sci. Med. 2009, 8, 374-380.

55. Lovell, R.; Towlson, C.; Parkin, G.; Portas, M.; Vaeyens, R.; Cobley, S. Soccer player characteristics in English lower-league development programmes: The relationships between relative age, maturation, anthropometry and physical fitness. PLoS ONE 2015, 10, e0137238. [CrossRef]

56. Matthys, S.P.J.; Vaeyens, R.; Vandendriessche, J.; Vandorpe, B.; Pion, J.; Coutts, A.J.; Lenoir, M.; Philippaerts, R.M. A multidisciplinary identification model for youth handball. Eur. J. Sport Sci. 2011, 11, 355-363. [CrossRef]

57. Muller, L.; Muller, E.; Kornexl, E.; Raschner, C. The Relationship Between Physical Motor Skills, Gender and Relative Age Effects in Young Austrian Alpine Ski Racers. Int. J. Sports Sci. Coach. 2015, 10, 69-85. [CrossRef]

58. Nikolaidis, P.T.; Asadi, A.; Santos, E.J.A.M.; Calleja-González, J.; Padulo, J.; Chtourou, H.; Zemkova, E. Relationship of body mass status with running and jumping performances in young basketball players. Muscles Ligaments Tendons J. 2015, 5, 187-194. [CrossRef]

59. Nikolaidis, P.T. Age-predicted vs. measured maximal heart rate in young team sport athletes. Niger. Med. J. 2014, 55, 314-320. [CrossRef] [PubMed]

60. Opstoel, K.; Pion, J.; Elferink-Gemser, M.; Hartman, E.; Willemse, B.; Philippaerts, R.; Visscher, C. Anthropometric Characteristics, Physical Fitness and Motor Coordination of 9 to 11 Year Old Children Participating in a Wide Range of Sports. PLoS ONE 2015, 10, e0126282. [CrossRef] [PubMed]

61. Padulo, J.; Attene, G.; Ardigo, L.P.; Bragazzi, N.L.; Maffulli, N.; Zagatto, A.M.; Dello Iacono, A. Can a Repeated Sprint Ability Test Help Clear a Previously Injured Soccer Player for Fully Functional Return to Activity? A Pilot Study. Clin. J. Sport Med. 2017, 27, 361-368. [CrossRef] [PubMed]

62. Parsonage, J.R.; Williams, R.S.; Rainer, P.; McKeown, I.; Williams, M.D. Assessment of Conditioning-Specific Movement Tasks and Physical Fitness Measures in Talent Identified under 16-Year-Old Rugby Union Players. J. Strength Cond. Res. 2014, 28, 1497-1506. [CrossRef]

63. Pion, J.; Segers, V.; Fransen, J.; Debuyck, G.; Deprez, D.; Haerens, L.; Vaeyens, R.; Philippaerts, R.; Lenoir, M. Generic anthropometric and performance characteristics among elite adolescent boys in nine different sports. Eur. J. Sport Sci. 2015, 15, 357-366. [CrossRef]

64. Psotta, R.; Bunc, V.; Hendl, J.; Tenney, D.; Heller, J. Is repeated-sprint ability of soccer players predictable from field-based or laboratory physiological tests? J. Sports Med. Phys. Fit. 2011, 51, 18-25.

65. Rebelo, A.; Brito, J.; Maia, J.; Coelho-e-Silva, M.J.; Figueiredo, A.J.; Bangsbo, J.; Malina, R.M.; Seabra, A. Anthropometric characteristics, physical fitness and technical performance of under-19 soccer players by competitive level and field position. Int. J. Sports Med. 2013, 34, 312-317. [CrossRef]

66. Saavedra, J.M.; Escalante, Y.; Rodriguez, F.A. A multivariate analysis of performance in young swimmers. Pediatr. Exerc. Sci. 2010, 22, 135-151. [CrossRef] 
67. Spencer, M.; Pyne, D.; Santisteban, J.; Mujika, I. Fitness determinants of repeated-sprint ability in highly trained youth football players. Int. J. Sports Physiol. Perform. 2011, 6, 497-508. [CrossRef]

68. Stewart, P.F.; Turner, A.N.; Miller, S.C. Reliability, factorial validity, and interrelationships of five commonly used change of direction speed tests. Scand. J. Med. Sci. Sports 2014, 24, 500-506. [CrossRef]

69. Till, K.; Cobley, S.; O'Hara, J.; Brightmore, A.; Cooke, C.; Chapman, C. Using anthropometric and performance characteristics to predict selection in junior UK Rugby League players. J. Sci. Med. Sport 2011, 14, 264-269. [CrossRef] [PubMed]

70. Tsoulfa, K.; Dalamitros, A.A.; Manou, V.; Stavropoulos, N.; Kellis, S. Can a one-day field testing discriminate between competitive and noncompetitive preteen tennis players? J. Phys. Educ. Sport 2016, 16, 1075-1077.

71. Ulbricht, A.; Fernandez-Fernandez, J.; Mendez-Villanueva, A.; Ferrauti, A. Impact of Fitness Characteristics on Tennis Performance in Elite Junior Tennis Players. J. Strength Cond. Res. 2016, 30, 989-998. [CrossRef] [PubMed]

72. Vandorpe, B.; Vandendriessche, J.; Vaeyens, R.; Pion, J.; Lefevre, J.; Philippaerts, R.; Lenoir, M. Factors discriminating gymnasts by competitive level. Int. J. Sports Med. 2011, 32, 591-597. [CrossRef] [PubMed]

73. Vandorpe, B.; Vandendriessche, J.B.; Vaeyens, R.; Pion, J.; Lefevre, J.; Philippaerts, R.M.; Lenoir, M. The value of a non-sport-specific motor test battery in predicting performance in young female gymnasts. J. Sports Sci. 2012, 30, 497-505. [CrossRef] [PubMed]

74. Vanttinen, T.; Blomqvist, M.; Luhtanen, P.; Hakkinen, K. Effects of Age and Soccer Expertise on General Tests of Perceptual and Motor Performance among Adolescent Soccer Players. Percept. Mot. Ski. 2010, 110, 675-692. [CrossRef] [PubMed]

75. Aschendorf, P.F.; Zinner, C.; Delextrat, A.; Engelmeyer, E.; Mester, J. Effects of basketball-specific high-intensity interval training on aerobic performance and physical capacities in youth female basketball players. Physician Sportsmed. 2019, 47, 65-70. [CrossRef] [PubMed]

76. Carling, C.; le Gall, F.; Reilly, T.; Williams, A.M. Do anthropometric and fitness characteristics vary according to birth date distribution in elite youth academy soccer players? Scand. J. Med. Sci. Sports 2009, 19, 3-9. [CrossRef]

77. Jones, B.; Weaving, D.; Tee, J.; Darrall-Jones, J.; Weakley, J.; Phibbs, P.; Read, D.; Roe, G.; Hendricks, S.; Till, K. Bigger, stronger, faster, fitter: The differences in physical qualities of school and academy rugby union players. J. Sports Sci. 2018, 36, 2399-2404. [CrossRef]

78. Lopez-Plaza, D.; Alacid, F.; Muyor, J.M.; Lopez-Minarro, P.A. Differences in Anthropometry, Biological Age and Physical Fitness Between Young Elite Kayakers and Canoeists. J. Hum. Kinet. 2017, 57, 181-190. [CrossRef]

79. Lopez-Plaza, D.; Alacid, F.; Rubio, J.A.; Lopez-Minarro, P.A.; Muyor, J.M.; Manonelles, P. Morphological and physical fitness profile of young female sprint kayakers. J. Strength Cond. Res. 2019, 33, 1963-1970. [CrossRef] [PubMed]

80. Höner, O.; Votteler, A. Prognostic relevance of motor talent predictors in early adolescence: A group- and individual-based evaluation considering different levels of achievement in youth football. J. Sports Sci. 2016, 34, 2269-2278.

81. Montosa, I.; Vernetta, M.; López-Bedoya, J. Assessment of health-related fitness by the ALPHA-fitness test battery in girls and adolescents who practise rhythmic gymnastics. J. Hum. Sport Exerc. 2018, 13, 188-204. [CrossRef]

82. Romanenko, V.; Podrigalo, L.; Iermakov, S.; Rovnaya, O.; Tolstoplet, E.; Tropin, Y.; Goloha, V. Functional state of martial arts athletes during implementation process of controlled activity-Comparative analysis. Phys. Act. Rev. 2018, 6, 87-93. [CrossRef]

83. Stoggl, R.; Muller, E.; Stoggl, T. Motor abilities and anthropometrics in youth cross-country skiing. Scand. J. Med. Sci. Sports 2015, 25, E70-E81. [CrossRef]

84. Till, K.; Morley, D.; O’Hara, J.; Jones, B.L.; Chapman, C.; Beggs, C.B.; Cooke, C.; Cobley, S. A retrospective longitudinal analysis of anthropometric and physical qualities that associate with adult career attainment in junior rugby league players. J. Sci. Med. Sport 2017, 20, 1029-1033. [CrossRef]

85. Delextrat, A.; Grosgeorge, B.; Bieuzen, F. Determinants of Performance in a New Test of Planned Agility for Young Elite Basketball Players. Int. J. Sports Physiol. Perform. 2015, 10, 160-165. [CrossRef]

86. Di Cagno, A.; Battaglia, C.; Fiorilli, G.; Piazza, M.; Giombini, A.; Fagnani, F.; Borrione, P.; Calcagno, G.; Pigozzi, F. Motor Learning as Young Gymnast's Talent Indicator. J. Sports Sci. Med. 2014, 13, 767-773. 
87. Jakovljevic, S.T.; Karalejic, M.S.; Pajic, Z.B.; Macura, M.M.; Erculj, F.F. Speed and Agility of 12-and 14-Year-Old Elite Male Basketball Players. J. Strength Cond. Res. 2012, 26, 2453-2459. [CrossRef]

88. Kamandulis, S.; Venckunas, T.; Masiulis, N.; Matulaitis, K.; Balčiunas, M.; Peters, D.; Skurvydas, A. Relationship between general and specific coordination in 8- to 17-year-old male basketball players. Percept. Mot. Ski. 2013, 117, 821-836. [CrossRef]

89. Karpowicz, K.; Karpowicz, M.; Strzelczyk, R. Structure of Physical Fitness among Young Female Basketball Players (Trends of Changes in 2006-2013). J. Strength Cond. Res. 2015, 29, 2745-2757. [CrossRef] [PubMed]

90. Marin, P.J.; Torres-Luque, G.; Hernandez-Garcia, R.; Garcia-Lopez, D.; Garatachea, N. Effects of Different Vibration Exercises on Bench Press. Int. J. Sports Med. 2011, 32, 743-748. [CrossRef] [PubMed]

91. Matthys, S.P.J.; Vaeyens, R.; Fransen, J.; Deprez, D.; Pion, J.; Vandendriessche, J.; Vandorpe, B.; Lenoir, M. A longitudinal study of multidimensional performance characteristics related to physical capacities in youth handball. J. Sports Sci. 2013, 31, 325-334. [CrossRef] [PubMed]

92. Moss, S.L.; McWhannell, N.; Michalsik, L.B.; Twist, C. Anthropometric and physical performance characteristics of top-elite, elite and non-elite youth female team handball players. J. Sports Sci. 2015, 33, 1780-1789. [CrossRef] [PubMed]

93. Nikolaidis, P.T.; Gkoudas, K.; Afonso, J.; Clemente-Suarez, V.J.; Knechtle, B.; Kasabalis, S.; Kasabalis, A.; Douda, H.; Tokmakidis, S.; Torres-Luque, G. Who jumps the highest? Anthropometric and physiological correlations of vertical jump in youth elite female volleyball players. J. Sports Med. Phys. Fit. 2017, 57, 802-810.

94. Nikolaidis, P.T.; Afonso, J.; Clemente-Suarez, V.J.; Alvarado, J.R.P.; Driss, T.; Knechtle, B.; Torres-Luque, G. Jumping Tests versus Wingate Anaerobic Test in Female Volleyball Players: The Role of Age. Sports 2016, 4, 9. [CrossRef]

95. Perroni, F.; Pintus, A.; Frandino, M.; Guidetti, L.; Baldari, C. Relationship among Repeated Sprint Ability, Chronological Age, and Puberty in Young Soccer Players. J. Strength Cond. Res. 2018, 32, 364-371. [CrossRef]

96. Pion, J.A.; Fransen, J.; Deprez, D.N.; Segers, V.I.; Vaeyens, R.; Philippaerts, R.M.; Lenoir, M. Stature and Jumping Height Are Required in Female Volleyball, but Motor Coordination Is a Key Factor for Future Elite Success. J. Strength Cond. Res. 2015, 29, 1480-1485. [CrossRef]

97. Rommers, N.; Mostaert, M.; Goossens, L.; Vaeyens, R.; Witvrouw, E.; Lenoir, M.; D'Hondt, E. Age and maturity related differences in motor coordination among male elite youth soccer players. J. Sports Sci. 2019, 37, 196-203. [CrossRef]

98. Sogut, M. A Comparison of Serve Speed and Motor Coordination between Elite and Club Level Tennis Players. J. Hum. Kinet. 2017, 55, 171-176. [CrossRef]

99. Sogut, M. Gross motor coordination in junior tennis players. J. Sports Sci. 2016, 34, 2149-2152. [CrossRef] [PubMed]

100. Te Wierike, S.C.; de Jong, M.C.; Tromp, E.J.; Vuijk, P.J.; Lemmink, K.A.; Malina, R.M.; Elferink-Gemser, M.T.; Visscher, C. Development of repeated sprint ability in talented youth basketball players. J. Strength Cond. Res. 2014, 28, 928-934. [CrossRef] [PubMed]

101. Till, K.; Jones, B. Monitoring anthropometry and fitness using maturity groups within youth rugby league. J. Strength Cond. Res. 2015, 29, 730-736. [CrossRef] [PubMed]

102. Torres-Unda, J.; Zarrazquin, I.; Gravina, L.; Zubero, J.; Seco, J.; Gil, S.M.; Gil, J.; Irazusta, J. Basketball Performance Is Related to Maturity and Relative Age in Elite Adolescent Players. J. Strength Cond. Res. 2016, 30, 1325-1332. [CrossRef]

103. Vernillo, G.; Silvestri, A.; La Torre, A. The Yo-Yo Intermittent Recovery Test in Junior Basketball Players According to Performance Level and Age Group. J. Strength Cond. Res. 2012, 26, 2490-2494. [CrossRef] [PubMed]

104. Atl, H.; Koklu, Y.; Alemdaroglu, U.; Kocak, F.U. A Comparison of Heart Rate Response and Frequencies of Technical Actions between Half-Court and Full-Court 3-a-Side Games in High School Female Basketball Players. J. Strength Cond. Res. 2013, 27, 352-356. [CrossRef]

105. Cortis, C.; Tessitore, A.; Lupo, C.; Pesce, C.; Fossile, E.; Figura, F.; Capranica, L. Inter-limb coordination, strength, jump, and sprint performances following a youth men's basketball game. J. Strength Cond. Res. 2011, 25, 135-142. [CrossRef]

106. Kramer, T.; Huijgen, B.C.H.; Elferink-Gemser, M.T.; Visscher, C. Prediction of Tennis Performance in Junior Elite Tennis Players. J. Sports Sci. Med. 2017, 16, 14-21. 
107. Milic, M.; Grgantov, Z.; Katic, R. Impact of Biomotor Dimensions on Player Quality in Young Female Volleybal Players. Coll. Antropol. 2013, 37, 93-99.

108. Torreblanca-Martínez, V.; González-Jurado, J.A.; Otero-Saborido, F.M. Relationships between fitness test and kicking velocity in young soccer players. J. Sports Med. Phys. Fit. 2018, 58, 1190-1196.

109. Ziemann, E.; Sledziewska, E.; Grzywacz, T.; Gibson, A.L.; Wierzba, T.H. Body composition and physical capacity of elite adolescent female tennis players. Georgian Med. News 2011, 196, 19-27.

110. Nikolaidis, P.T. Body mass index and body fat percentage are associated with decreased physical fitness in adolescent and adult female volleyball players. J. Res. Med. Sci. 2013, 18, 22-26. [PubMed]

111. Melchiorri, G.; Viero, V.; Triossi, T.; Annino, G.; Padua, E.; Tancredi, V. Anthropometric and performance measures to study talent detection in youth volleyball. J. Sports Med. Phys. Fit. 2017, 57, 1623-1632.

112. Gil-Rey, E.; Lezaun, A.; Los Arcos, A. Quantification of the perceived training load and its relationship with changes in physical fitness performance in junior soccer players. J. Sports Sci. 2015, 33, 2125-2132. [CrossRef]

113. Sinovas, M.C.; Pérez-López, A.; Valverde, I.Á.; Cerezal, A.B.; Ramos-Campo, D.J.; Rubio-Arias, J.A.; Cerrato, D.V. Influence of body composition on vertical jump performance according with the age and the playing position in football players. Nutr. Hosp. 2015, 32, 299-307.

114. Faber, I.R.; Elferink-Gemser, M.T.; Oosterveld, F.G.J.; Twisk, J.W.R.; Nijhuis-Van der Sanden, M.W.G. Can an early perceptuo-motor skills assessment predict future performance in youth table tennis players? An observational study (1998-2013). J. Sports Sci. 2017, 35, 593-601. [CrossRef]

115. Alesi, M.; Bianco, A.; Padulo, J.; Vella, F.P.; Petrucci, M.; Paoli, A.; Palma, A.; Pepi, A. Motor and cognitive development: The role of karate. Muscles Ligaments Tendons J. 2014, 4, 114-120. [CrossRef]

116. Belka, J.; Hulka, K.; Safar, M.; Weisser, R.; Mikova, L. Analysis of the fitness level in elite handball players (U16 and U18) between 2003 and 2013. J. Phys. Educ. Sport 2016, 16, 1381-1390.

117. Filipcic, A.; Filipčič, T.; Leskosek, B. Differences in physical fitness among young tennis players in between 1992 and 2008. Coll. Antropol. 2015, 39, 131-143.

118. Brink, M.S.; Nederhof, E.; Visscher, C.; Schmikli, S.L.; Lemmink, K.A. Monitoring load, recovery, and performance in young elite soccer players. J. Strength Cond Res. 2010, 24, 597-603. [CrossRef]

119. Ortega, F.B.; Artero, E.G.; Ruiz, J.R.; Vicente-Rodriguez, G.; Bergman, P.; Hagstromer, M.; Ottevaere, C.; Nagy, E.; Konsta, O.; Rey-Lopez, J.P.; et al. Reliability of health-related physical fitness tests in European adolescents. The HELENA Study. Int. J. Obes. 2008, 32, S49-S57. [CrossRef] [PubMed]

120. Castro-Pinero, J.; Ortega, F.B.; Artero, E.G.; Girela-Rejon, M.J.; Mora, J.; Sjostrom, M.; Ruiz, J.R. Assessing Muscular Strength in Youth: Usefulness of Standing Long Jump as a General Index of Muscular Fitness. J. Strength Cond. Res. 2010, 24, 1810-1817. [CrossRef] [PubMed]

121. Waldo, B. Grip strength testing. Strength Cond. J. 1996, 18, 32-35. [CrossRef]

122. Innes, E. Handgrip strength testing: A review of the literature. Aust. Occup. Ther. J. 1999, 46, 120-140. [CrossRef]

123. Roberts, H.C.; Denison, H.J.; Martin, H.J.; Patel, H.P.; Syddall, H.; Cooper, C.; Sayer, A.A. A review of the measurement of grip strength in clinical and epidemiological studies: Towards a standardised approach. Age Ageing 2011, 40, 423-429. [CrossRef]

124. Cronin, J.; Lawton, T.; Harris, N.; Kilding, A.; McMaster, D.T. A Brief Review of Handgrip Strength and Sport Performance. J. Strength Cond. Res. 2017, 31, 3187-3217. [CrossRef]

125. Stockbrugger, B.A.; Haennel, R.G. Validity and reliability of a medicine ball explosive power test. J. Strength Cond. Res. 2001, 15, 431-438.

126. Ikeda, Y.; Kijima, K.; Kawabata, K.; Fuchimoto, T.; Ito, A. Relationship between side medicine-ball throw performance and physical ability for male and female athletes. Eur. J. Appl. Physiol. 2007, 99, 47-55. [CrossRef]

127. Davis, K.L.; Kang, M.; Boswell, B.B.; DuBose, K.D.; Altman, S.R.; Binkley, H.M. Validity and Reliability of the Medicine Ball Throw for Kindergarten Children. J. Strength Cond. Res. 2008, 22, 1958-1963. [CrossRef]

128. Tarara, D.T.; Fogaca, L.K.; Taylor, J.B.; Hegedus, E.J. Clinician-friendly physical performance tests in athletes part 3: A systematic review of measurement properties and correlations to injury for tests in the upper extremity. Br. J. Sports Med. 2016, 50, 545-551. [CrossRef]

129. Salonia, M.A.; Chu, D.A.; Cheifetz, P.M.; Freidhoff, G.C. Upper-body power as measured by medicine-ball throw distance and its relationship to class level among 10- and 11-year-old female participants in club gymnastics. J. Strength Cond. Res. 2004, 18, 4695-4702. 
130. Harris, C.; Wattles, A.P.; DeBeliso, M.; Sevene-Adams, P.G.; Berning, J.M.; Adams, K.J. The Seated Medicine Ball Throw as a Test of Upper Body Power in Older Adults. J. Strength Cond. Res. 2011, 25, 2344-2348. [CrossRef] [PubMed]

131. Artero, E.G.; Espana-Romero, V.; Castro-Pinero, J.; Ortega, F.B.; Suni, J.; Castillo-Garzon, M.J.; Ruiz, J.R. Reliability of field-based fitness tests in youth. Int. J. Sports Med. 2011, 32, 159-169. [CrossRef] [PubMed]

132. Koklu, Y.; Alemdaroglu, U.; Kocak, F.U.; Erol, A.E.; Findikoglu, G. Comparison of Chosen Physical Fitness Characteristics of Turkish Professional Basketball Players by Division and Playing Position. J. Hum. Kinet. 2011, 30, 99-106. [CrossRef]

133. Koropanovski, N.; Berjan, B.; Bozic, P.R.; Pazin, N.; Sanader, A.; Jovanovic, S.; Jaric, S. Anthropometric and Physical Performance Profiles of Elite Karate Kumite and Kata Competitors. J. Hum. Kinet. 2011, 30, 107-114. [CrossRef]

134. Aslan, A. Cardiovascular Responses, Perceived Exertion and Technical Actions During Small-Sided Recreational Soccer: Effects of Pitch Size and Number of Players. J. Hum. Kinet. 2013, 38, 95-105. [CrossRef]

135. Ahmaidi, S.; Adam, B.; Préfaut, C. Validity of the 20-M shuttle run test and the track test to estimate the maximal oxygen uptake in athletes. Sci. Sports 1990, 5, 71-76. [CrossRef]

136. Castro-Pinero, J.; Artero, E.G.; Espana-Romero, V.; Ortega, F.B.; Sjostrom, M.; Suni, J.; Ruiz, J.R. Criterion-related validity of field-based fitness tests in youth: A systematic review. Br. J. Sports Med. 2010, 44, 934-943. [CrossRef]

137. Wilkinson, D.M.; Fallowfield, J.L.; Myers, S.D. A modified incremental shuttle run test for the determination of peak shuttle running speed and the prediction of maximal oxygen uptake. J. Sports Sci. 1999, 17, 413-419. [CrossRef]

138. Leger, L.A.; Lambert, J. A maximal multistage 20-m shuttle run test to predict VO2 max. Eur. J. Appl. Physiol. Occup. Physiol. 1982, 49, 1-12. [CrossRef]

139. Paliczka, V.J.; Nichols, A.K.; Boreham, C.A. A multi-stage shuttle run as a predictor of running performance and maximal oxygen uptake in adults. Br. J. Sports Med. 1987, 21, 163-165. [CrossRef] [PubMed]

140. Lang, J.J.; Tremblay, M.S.; Leger, L.; Olds, T.; Tomkinson, G.R. International variability in $20 \mathrm{~m}$ shuttle run performance in children and youth: Who are the fittest from a 50-country comparison? A systematic literature review with pooling of aggregate results. Br. J. Sports Med. 2018, 52, 276. [CrossRef] [PubMed]

141. Hachana, Y.; Chaabene, H.; Nabli, M.A.; Attia, A.; Moualhi, J.; Farhat, N.; Elloumi, M. Test-retest reliability, criterion-related validity, and minimal detectable change of the Illinois agility test in male team sport athletes. J. Strength Cond. Res. 2013, 27, 2752-2759. [CrossRef] [PubMed]

142. Castro-Pinero, J.; Gonzalez-Montesinos, J.L.; Keating, X.D.; Mora, J.; Sjostrom, M.; Ruiz, J.R. Percentile Values for Running Sprint Field Tests in Children Ages 6-17 Years: Influence of Weight Status. Res. Q. Exerc. Sport 2010, 81, 143-151. [CrossRef] [PubMed]

143. Vanhelst, J.; Beghin, L.; Fardy, P.S.; Ulmer, Z.; Czaplicki, G. Reliability of health-related physical fitness tests in adolescents: The MOVE Program. Clin. Physiol. Funct. Imaging 2016, 36, 106-111. [CrossRef]

144. Buchheit, M.; Mendez-Villanueva, A.; Delhomel, G.; Brughelli, M.; Ahmaidi, S. Improving Repeated Sprint Ability in Young Elite Soccer Players: Repeated Shuttle Sprints Vs. Explosive Strength Training. J. Strength Cond. Res. 2010, 24, 2715-2722. [CrossRef]

145. Nebil, G.; Zouhair, F.; Hatem, B.; Hamza, M.; Zouhair, T.; Roy, S.; Ezdine, B. Effect of optimal cycling repeated-sprint combined with classical training on peak leg power in female soccer players. Isokinet. Exerc. Sci. 2014, 22, 69-76. [CrossRef]

146. Taylor, J.; Macpherson, T.; Spears, I.; Weston, M. The Effects of Repeated-Sprint Training on Field-Based Fitness Measures: A Meta-Analysis of Controlled and Non-Controlled Trials. Sports Med. 2015, 45, 881-891. [CrossRef]

147. Watowicz, R.P.; Anderson, S.E.; Kaye, G.L.; Taylor, C.A. Energy Contribution of Beverages in US Children by Age, Weight, and Consumer Status. Child. Obes. 2015, 11, 475-483. [CrossRef]

148. Vescovi, J.D.; McGuigan, M.R. Relationships between sprinting, agility, and jump ability in female athletes. J. Sports Sci. 2008, 26, 97-107. [CrossRef]

149. Raya, M.A.; Gailey, R.S.; Gaunaurd, I.A.; Jayne, D.M.; Campbell, S.M.; Gagne, E.; Manrique, P.G.; Muller, D.G.; Tucker, C. Comparison of three agility tests with male servicemembers: Edgren Side Step Test, T-Test, and Illinois Agility Test. J. Rehabil. Res. Dev. 2013, 50, 951-960. [CrossRef] [PubMed] 
150. Kutlu, M.; Yapici, H.; Yilmaz, A. Reliability and Validity of a New Test of Agility and Skill for Female Amateur Soccer Players. J. Hum. Kinet. 2017, 56, 219-227. [CrossRef] [PubMed]

151. Negra, Y.; Chaabene, H.; Hammami, M.; Amara, S.; Sammoud, S.; Mkaouer, B.; Hachana, Y. Agility in Young Athletes: Is It a Different Ability from Speed and Power? J. Strength Cond. Res. 2017, 31, 727-735. [CrossRef]

152. Vandorpe, B.; Vandendriessche, J.; Lefevre, J.; Pion, J.; Vaeyens, R.; Matthys, S.; Philippaerts, R.; Lenoir, M. The KorperkoordinationsTest fur Kinder: Reference values and suitability for 6-12-year-old children in Flanders. Scand. J. Med. Sci. Sports 2011, 21, 378-388. [CrossRef] [PubMed]

153. Iivonen, S.K.; Sääkslahti, A.; Laukkanen, A. A review of studies using the Körperkoordinationstest für Kinder (KTK). Eur. J. Adapt. Phys. Act. 2015, 8, 18-36. [CrossRef]

154. Iivonen, S.; Sääkslahti, A.; Laukkanen, A. Studies using the körperkoordinationstest für (ktk): A review. Sci. Sports 2014, 29, 21. [CrossRef]

155. Jette, M.; Kimick, A.; Sidney, K. Evaluating the Occupational Physical-Fitness of Canadian Forces Infantry Personnel. Mil. Med. 1989, 154, 318-322. [CrossRef]

156. Sporis, G.; Harasin, D.; Bok, D.; Matika, D.; Vuleta, D. Effects of a Training Program for Special Operations Battalion on Soldiers' Fitness Characteristics. J. Strength Cond. Res. 2012, 26, 2872-2882. [CrossRef]

157. Patrick, S.K.; Noah, J.A.; Yang, J.F. Interlimb Coordination in Human Crawling Reveals Similarities in Development and Neural Control with Quadrupeds. J. Neurophysiol. 2009, 101, 603-613. [CrossRef]

158. Petrigna, L.; Karsten, B.; Marcolin, G.; Paoli, A.; D’Antona, G.; Palma, A.; Bianco, A. A Review of Countermovement and Squat Jump Testing Methods in the Context of Public Health Examination in Adolescence: Reliability and Feasibility of Current Testing Procedures. Front. Physiol. 2019, 10, 1384. [CrossRef]

159. Bianco, A.; Mammina, C.; Jemni, M.; Filippi, A.R.; Patti, A.; Thomas, E.; Paoli, A.; Palma, A.; Tabacchi, G. A Fitness Index model for Italian adolescents living in Southern Italy: The ASSO project. J. Sports Med. Phys. Fit. 2016, 56, 1279-1288.

(C) 2019 by the authors. Licensee MDPI, Basel, Switzerland. This article is an open access article distributed under the terms and conditions of the Creative Commons Attribution (CC BY) license (http://creativecommons.org/licenses/by/4.0/). 